\title{
Anthropometric and body-mass composition suggests an intrinsic feature in Williams-Beuren syndrome
}

\author{
Roberto José Negrão Nogueira², Leonardo Ferreira Zimmerman², Yara Maria Franco Moreno³, Cláudia Regina Comparinı, \\ Danilo Vilela Viana ${ }^{5}$, Tarsis Antonio Paiva Vieira ${ }^{6}$, Carlos Eduardo Steiner ${ }^{7}$, Vera Lúcia Gill-da-Silva-Lopes ${ }^{8}$ \\ ${ }^{1}$ PhD; Assistant Physician, Universidade Estadual de Campinas (UNICAMP), Campinas, SP, Brazil \\ ${ }^{2}$ Physician, Saúde Medicol S.A. - Grupo Nossa Senhora de Lourdes, São Paulo, SP, Brazil \\ ${ }^{3} \mathrm{PhD}$, Professor, Universidade de Santa Catarina (USC), Florianópolis, SC, Braz \\ ${ }^{4}$ Nurse, UNICAMP, Campinas, SP, Brazil \\ ${ }^{5}$ Physician, Universidade Federal de Mato Grosso (UFMT), Cuiabá, MT, Brazi \\ ${ }^{6} \mathrm{MSc}$, Cytogeneticist, UNICAMP, Campinas, SP, Brazil \\ ${ }^{7}$ PhD, Professor, UNICAMP, Campinas, SP, Brazil \\ ${ }^{8}$ Associate Professor, Department of Medical Genetics, UNICAMP, Campinas, SP, Brazil
}

Study conducted at the Department of Medical Genetics, Faculdade de Ciências Médicas, Universidade de Campinas (FCM-UNICAMP), Campinas, São Paulo, SP, Brazil

Submitted on: 05/16/2011 Approved on: 09/26/2011

Correspondence to: Vera Lúcia Gil-da-Silva-Lopes Rua Tessália Vieira de Camargo, 126 CEP: 13083-887,

Campinas, SP, Brazil Phone: 55 (19) 3521-8909 vlopes@fcm.unicamp.br

Conflict of interest: None.

(C)2011 Elsevier Editora Ltda. Todos os direitos reservados.

\section{SUMMARY}

Objective: Although considered a well-known condition, there is only one study describing the body composition among individuals with Williams-Beuren syndrome. The aim was to characterize the nutritional status in Brazilian individuals with this condition. Methods: Cross-sectional study was designed to evaluate clinical and nutritional data of 17 Brazilian patients. Z-scores for height, weight, body mass index, triceps and subscapular skinfold thickness, arm circumference, arm muscle area, arm fat area were calculated. Wilcoxon's test was used to investigate differences between the z-scores of the anthropometrical measures and zero. Results: Four children were considered stunted and two severely malnourished. The $\mathrm{z}$-score mean value for height was $-1.14 \pm 1.00$ ( $\mathrm{p}$-value $=0.004$ ), for weight, $-0.67 \pm 1.19$ ( $\mathrm{p}$-value $=0.0443)$, for arm circumference, $-0.94 \pm 1.14$ ( $\mathrm{p}$-value $=0.0222)$, for triceps skinfold thickness, $-0.59 \pm 0.63$ ( $\mathrm{p}$-value $=0.0042$ ) and for arm fat area $-0.67 \pm 0.67$ ( $\mathrm{p}$-value $=0.0061)$. Conclusion: Short stature seen in this series confirms a previous study describing this feature in a German population, which would suggest it as an intrinsic feature in Williams-Beuren syndrome. In addition, skinfold thickness measures have not been previously performed in this syndrome and detected abnormalities in fat stores in this sample. Considering this method a fast and low-cost way to evaluate body composition, similar studies could be performed in other populations in order to better characterize this issue. Morbidity related with this genetics condition and information for clinical investigation and clinical follow-up are also discussed.

Keywords: Natural history; nutritional status; body composition; Williams syndrome.

\section{Resumo}

\section{Antropometria e composição de massa corporal sugerem achado intrínseco da síndrome de Williams-Beuren}

Objetivo: Embora a síndrome de Williams-Beuren seja bem conhecida, há apenas um estudo descrevendo a composição corporal nesses pacientes. O objetivo foi caracterizar o estado nutricional de brasileiros com síndrome de Williams. Métodos: Utilizou-se um estudo transversal com a avaliação de dados clínicos e nutricionais de 17 pacientes. Foram calculados os escores-z do peso, estatura, índice de massa corpórea, dobras cutâneas, circunferência do braço e áreas muscular e adiposa do braço. Para verificar diferenças, foi utilizado o teste de Wilcoxon, sendo considerado significativo $p<0,05$. Resultados: Os valores médios dos escores- $z$ foram: $-1,14 \pm 1,00(p=0,004)$ para estatura, $-0,67 \pm 1,19(\mathrm{p}=0,0443)$ para peso, $-0,94 \pm 1,14(\mathrm{p}=0,0222)$ para a circunferência do braço, $-0,59 \pm 0,63(\mathrm{p}=0,0042)$ para dobra cutânea do tríceps e $-0,67 \pm 0,67(\mathrm{p}=0,0061)$ para a área gordurosa do braço. Foi observada desnutrição pregressa em quatro pacientes e crônica, em dois. Conclusão: A baixa estatura, semelhante à descrita na população alemã, parece ser intrínseca à síndrome. Esse foi o primeiro estudo que avaliou a composição corporal, utilizando as dobras cutâneas, e detectou anormalidades nas reservas de gordura. O método aqui utilizado é simples, rápido e de baixo custo, facilitando estudos similares em outras populações. Isso poderia melhor caracterizar esses aspectos na síndrome de Williams. Morbidade relacionada a essa doença e informações para investigação e seguimento clinico são discutidas.

Unitermos: História natural; estado nutricional; composição corporal; síndrome de Williams. 


\section{INTRODUCTION}

The improvement of health care along the years has been saving individuals, including those with genetic disorders, who have been experiencing an increase in their life expectancy. It brings the challenge to better understand the natural history of these conditions and planning a clinical follow up, which is essential for pediatric care. One of the well-known genetic disorders is the Williams-Beuren syndrome (WBS), with an estimate frequency of around $1: 20.000^{1}$. It is a contiguous gene syndrome, i.e., it is caused by haploinsuficiency due to microdeletions in chromosome 7q11.23 involving the genes of elastin LIM kinase 1, and probably RFC2 and CYLN2. Diagnosis can be confirmed by DNA analysis or fluorescent in situ hybridization (FISH) technique. Most cases are de novo occurrences, but occasionally, parent-to-child transmission is observed, as an autosomal dominant trait ${ }^{2}$.

WBS is characterized by mental retardation, congenital cardiac defect (mainly supravalvular aortic stenosis), outgoing personality, and typical facies usually described as "elfin facies". A stellate iris pattern is also considered a typical feature of this disorder. Hypercalcemia has been an infrequent finding and can be detected only within the first months of life $e^{2}$. Other congenital abnormalities, as well as performance and growth deficiencies occur in variable degrees among affected individuals ${ }^{3}$. Although variable, short stature may occur in as many as $50 \%$ of the patients with the syndrome $e^{4-6}$.

There are specific medical recommendations for management of these individuals ${ }^{7}$, but knowledge about physiopathology still remains limited. There is only one previous study describing a characteristic body composition among these patients ${ }^{8}$. In this article, we present further body composition parameters in a different population of WBS, which could be important for a better understanding of this condition and also for pediatric management.

This study reports the anthropometrical findings in a sample of individuals with the diagnosis of WBS. In order to evaluate the stature and BMI status of Brazilian WBS, patients from two German WBS populations were used to compare the findings herein exposed.

\section{Methods}

Seventeen individuals with WBS were evaluated. Diagnosis was based on clinical criteria as shown on Table 1 and confirmed by FISH analysis $\left(\mathrm{Vysis}^{\oplus}\right)$. In fact, the Preus index is a score based on clinical observation in patients with WBS and it is an useful tool to determine further investigation for WBS. Typical facies were defined by the presence of periorbital fullness of subcutaneous tissues, anteverted nares, long philtrum, prominent lips, and open mouth. Individuals were considered to have the typical facies by three clinical geneticists with large experience in dysmorphology.
Table 1 - Main clinical findings detected in this sample based on Preus index modified by Sugayama ${ }^{6}$

\begin{tabular}{lccc}
\hline Item & Points & Frequency & $\%$ \\
\hline $\begin{array}{l}\text { Delayed neuromotor } \\
\text { development }\end{array}$ & 2 & $17 / 17$ & 100 \\
$\begin{array}{l}\text { Auditive } \\
\text { hypersensitivity }\end{array}$ & 1 & $16 / 17$ & 94.1 \\
Typical facies & 3 & $16 / 17$ & 94.1 \\
Outgoing personality & 3 & $15 / 17$ & 88.2 \\
Feeding problems & 3 & $13 / 17$ & 76.5 \\
Low weight & 1 & $12 / 17$ & 70.5 \\
Mental deficiency & 3 & $12 / 17$ & 70.5 \\
Strabismus & 2 & $10 / 17$ & 58.8 \\
Supravalvular aortic & 3 & $10 / 17$ & 58.8 \\
stenosis & 3 & $9 / 17$ & 53 \\
Chronic constipation & 1 & $5 / 17$ & 29.4 \\
Hypertension & 1 & $5 / 17$ & 29.4 \\
Joint contractures & 1 & $2 / 17$ & 11.7 \\
Other structural & 1 & $1 / 17$ & 5.8 \\
cardiac defect* & & & \\
Ungueal hypoplasia & & & \\
\hline * pulmonary stenosis (2 individuals). & & \\
\hline
\end{tabular}

Outgoing personality was considered in individuals presenting an easy approach to strangers, a strong interest in others and a loquacious speech.

The cross-secctional study comprised the following steps: (a) identification, brief anamnesis and karyotype with FISH, (b) clinical and nutritional evaluation with anthropometrical measures including height and weight from the subjects and parents, as well as arm circumference, triceps and subscapular skinfold thickness from the subjects.

Anthropometrical data were measured by standard methods? . Weight was measured to $0.1 \mathrm{~kg}$ with a digital electronic stand on scale (PL 150, Personal Line, Filizola ${ }^{\circledR}$ ) and stature was measured to $0.1 \mathrm{~cm}$ with a stadiometer. Skinfolds were measured in triplicate by at least two trained examiners with a Lange skinfold caliper (Beta Tech Inc, Cambridge, Maryland) and arm circumference with a flexible non-stretch fiberglass tape.

This article had been previously approved by the Institutional Review Board of the Faculty of Medical Sciences, Universidade Estadual de Campinas (001/2004).

\section{DATA ANALYSIS}

National Center for Health Statistics reference standards $(\mathrm{NCHS})^{10}$ were used to calculate $\mathrm{z}$-scores (standardized scores) for height, weight and body mass index (BMI). BMI was calculated by dividing weight (in kilograms) by height squared (in meters). 
Other anthropometrical data (z-scores) for triceps and subscapular skinfold thickness, arm circumference, arm muscle area, and arm fat area were calculated according to Frisancho ${ }^{11}$. Parental target range (PTR) was estimated based upon Tanner et al. ${ }^{12}$ All data were obtained with the software program SISCRES (provided by Moreno, AM \& Marini SHVL, 2002 CIPED, FCM-UNICAMP).

\section{STATISTICAL ANALYSIS}

Statistics computations used The SAS System for Windows ${ }^{\oplus}$ (version 6.12; SAS Institute Inc, Cary, NC, USA). Descriptive data are expressed as mean \pm standard deviation (SD), median, minimum and maximum values.

Wilcoxon's test (sign rank test) for related samples was used to investigate significant differences between the $\mathrm{z}$ scores of the anthropometrical measures and zero.

In order to compare the stature and the BMI of Brazilian WBS patients with two German WBS populations ${ }^{13,14}$ z-scores were calculated based on the previously described means \pm SDs and then Wilcoxon's test was used. The significancy level was established at 0.05 .

\section{RESULTS}

The sample consisted of 12 males and 5 females, with a sex ratio of 2.4:1 and ages ranging from 2.6 to 18.3 years $(10.69 \pm 4.19$ years $)$.

\section{CLINICAL FINDINGS}

The most frequent signs were delayed neuromotor development in all cases, followed by typical facies, hyperacusia and outgoing personality in most individuals. Mental deficiency, supravalvular aortic stenosis and strabismus were also frequent, occurring in more than $50 \%$. On the other hand, low birth weight, hypertension, contractures and other congenital heart defects were seen in less than one third of the subjects, while nail hypoplasia was rare in this series, occurring in just one individual (Table 1).

Other reported abnormalities were recurrent pneumonias $(6 / 17)$, recurrent otitis $(2 / 17)$, and inguinal or umbilical hernias (5/17). Hypothyroidism, cryptorchidism, obstruction of lachrymal ducts, radioulnar synostosis, and epilepsy were described in one individual each.

The nutritional features observed in the first year of life included low birth weight $(6 / 17)$, feeding problems (13/17), constipation (9/17) and poor weight gain (12/17), as shown on Table 1.

\section{NUTRITIONAL STATUS}

Anthropometrical data are presented on Table 2. Regarding the nutritional status, four of the children were considered stunted and two severely malnourished.

Some anthropometrical z-scores observed were significantly lower than reference data. The z-score mean value for height was $-1.14 \pm 1.00$ ( $\mathrm{p}$-value $=0.004$ ), for weight,
Table 2 - Anthropometrical data of Williams-Beuren syndrome patients

\begin{tabular}{lccc}
\hline Variables & z-score & $\mathrm{n}$ & $\begin{array}{c}\text { Wilcoxon's } \\
\text { Test } \\
(\mathrm{p} \text {-value) }\end{array}$ \\
\hline Weight for age & $-0.67 \pm 1.19^{\mathrm{b}}$ & 16 & $\mathbf{0 . 0 4 4 3}$ \\
Height for age & $-1.14 \pm 1.00$ & 16 & $\mathbf{0 . 0 0 4}$ \\
BMI & $0.03 \pm 0.88$ & 16 & 0.9799 \\
Arm & $-0.94 \pm 1.14$ & 13 & $\mathbf{0 . 0 2 2 2}$ \\
circumference & $-0.59 \pm 0.63$ & 15 & $\mathbf{0 . 0 0 4 2}$ \\
Triceps skinfold & $0.20 \pm 0.49$ & 15 & 0.0918 \\
$\begin{array}{l}\text { Subscapular } \\
\text { skinfold }\end{array}$ & $-0.67 \pm 0.67$ & 13 & $\mathbf{0 . 0 0 6 1}$ \\
Arm fat area & $-0.67 \pm 1.26$ & 13 & 0.0942 \\
Arm muscle area & $-0.22 \pm 0.65$ & 15 & 0.3180 \\
Skinfold sum & -15
\end{tabular}

BMI, body mass index $\left(\mathrm{kg} / \mathrm{m}^{2}\right)$; ${ }^{\text {a }}$-values related to Wilcoxon's test used to investigate significant differences $(p<0.05)$ between z-scores and zero; ${ }^{b}$ mean \pm standard deviation.

$-0.67 \pm 1.19(\mathrm{p}$-value $=0.0443)$, for arm circumference, $-0.94 \pm 1.14$ (p-value $=0.0222$ ), for triceps skinfold thickness, $-0.59 \pm 0.63$ (p-value $=0.0042$ ) and for arm fat area $-0.67 \pm 0.67$ (p-value $=0.0061)$. A significant decrease in subscapular skinfold thickness $(0.33 \pm 0.42$; p-value $=0.0078)$ and arm muscle area $z$-score values $(-1.06 \pm 1.08, \mathrm{p}$-value $=0.0273)$ was observed when male patients were analysed separately. In relation to these patients' height, thirteen of them $(76.47 \%)$ were in accordance with their PTR ${ }^{12}$.

There was no difference in height $(\mathrm{p}=0.3225)$ and BMI $(\mathrm{p}=0.1046)$ between Brazilian and previously described German WBS patients ${ }^{12,13}$.

\section{Discussion}

In this WBS population, height for age, weight for age, arm circumference, triceps skinfold thickness and arm fat area were below reference data ${ }^{10}$. Growth deficiency, which was observed in this study, occurs in $50 \%$ of the individuals with this condition ${ }^{4,5,15}$. It is mainly detected in the first few years of life $e^{4,15,16}$, and it is possibly related to feeding difficulties, eating disorders, poor caloric intake, increased metabolic needs and progressive joint limitations ${ }^{4,15}$. Feeding problems were observed in $82.4 \%$, failure to thrive in $70.6 \%$, and constipation in $52.9 \%$. Similar values, i.e., $71 \%, 81 \%$ and $43 \%$ respectively, were obtained from a sample of 42 patients with WBS by Morris ${ }^{15}$.

The feeding problems such as those cited below and also dental anomalies, prolonged colic and gastroesophageal reflux lead to failure to thrive $e^{16,17}$. Part of these symptoms are also related to celiac disease, which seems 
to have a higher incidence in $\mathrm{WBS}^{18,19}$. Despite the absence of the diagnosis of celiac disease in this sample, in view of the design of the present study we cannot exclude this possibility. Considering the wide spectrum of symptoms of celiac disease, and the efficacy of the dietetic treatment, the investigation of this disorder in WBS could be justified.

Although the present subjects were shorter than National Center for Health Statistics (NCHS) children, most of them $(13 / 17 ; 76.5 \%)$ were found within their $\mathrm{PTR}^{12}$. Partsch et al. ${ }^{14}$, in a prospective longitudinal study in WBS, demonstrated that the adult boys' height was correlated to their parents' height, but the adult height of girls was only significantly correlated to their father's height. Another study ${ }^{5}$ reports that the adult height in WBS, when compared to the target height, presented a mean deficit of $10.2 \mathrm{~cm}$ in female and $9.1 \mathrm{~cm}$ in male subjects.

These results indicate that Brazilian and German WBS patients' mean heights are significantly similar and both are shorter than NCHS, which suggests that this feature is a consistent finding in this condition, independently of the ethnic background.

The mean weight for age in this sample was significantly lower than NCHS. As mean BMI was within the normal range in this sample, weight deficit was not considered a relevant finding. Similar results on BMI were observed by Kaplan et al. ${ }^{8}$ in six individuals with WBS.

Additionally, Kaplan et al. ${ }^{8}$ found, in their adolescents and adults sample with WBS, a similar dietary intake but a lower body fat than in healthy control subjects. In this paper, the authors concluded that a higher rest expenditure energy (REE) may contribute to the reduction of the total body fat stores of people with WBS. In the present study, using a different technique, we also found a reduction of the total body fat stores, but it was not possible to make the REE. Considering the lower age of the individuals involved in this study $(10.69 \pm 4.19$ years), the high incidence of feeding problems might contribute to this fact.

Decreased body fat stores (arm fat area, arm circumference and triceps skinfold thickness) were found in the present sample. Kaplan et al. ${ }^{8}$ by using bioelectrical impedance analysis, also reported lack of body fat in a group of six patients, when compared to control subjects.

Body composition can be estimated by skinfold thickness measurement, a low-cost, fast and standardized method. To the best of our knowledge, this is the first study describing skinfold thickness measurement in WBS patients. Furthermore, reference data for arm circumference, triceps and subscapular skinfold thickness from the general population are available. Thus, different methods could provide the same information in different populations.

\section{ConcLusion}

Considering that both Brazilian and German WBS populations showed similar stature pattern, other population studies enrolling individuals with different ethnic backgrounds could confirm these findings as an intrinsic feature in this condition. Similarly, additional studies of body composition using skinfold thickness could provide further information about this issue in WBS.

Nevertheless, growth deficiency on WBS could be aggravated due to common feeding problems during the first five years of life. Therefore, a multiprofessional approach, including early nutritional intervention and the use of concentrated formulas could be useful.

\section{AcKNOWLEDGEMENTS}

The authors wish to thank the patients, their relatives, and the Associação Brasileira de Síndrome de Williams (ABSW) in the name of its chairperson, Mrs. Juvelina Nunes, for their kind reception. This study is dedicated to her daughter. Special thanks also to Dr. Daniela Varela Luquetti and Dietitians Antonia Lenny Gomes Lazarini and Daniela Vicinansa Mônaco, for their assistance.

\section{RefERENCES}

1. Stromme P, Bjornstad PG, Ramstad K. Prevalence estimation of Williams syndrome. J Child Neurol. 2002;17(4):269-71.

2. SMM. Estudo clínico-genético e citogenética molecular pela técnica da hibridização in situ por fluorescência (FISH) em pacientes com síndrome de Williams-Beuren [thesis]. São Paulo: Universidade de São Paulo; 2001.

3. Jones KL. Smith's recognizable patterns of human malformation. $5^{\text {th }}$ ed. Philadelphia: W.B. Saunders; 1997.

4. Partsch CJ, Pankau R, Blum WF, Gosch A, Wessel A. Hormonal regulation in children and adults with Williams-Beuren syndrome. Am J Med Genet. 1994;51(3):251-7.

5. Pankau R, Partsch CJ, Gosch A, Oppermann HC, Wessel A. Statural growth in Williams-Beuren syndrome. Eur J Pediatr. 1992:151(10):751-5.

6. Preus M. The Williams syndrome: objective definition and diagnosis. Clin Genet. 1984;25(5):422-8.

7. Síndrome de Williams-Beuren. [cited 2010 nov 10]. Available from: http://www.ncbi.nlm.nih.gov/sites/GeneTests

8. Kaplan AS, Stallings VA, Zemel BS, Green KA, Kaplan P. Body composition, energy expenditure, and energy intake in patients with Williams syndrome. J Pediatr. 1998;132(2):223-7.

9. Lohman TG. Anthropometrical Standardization Reference Manual. Abridged edition. Champaign: Human Kinetics Books; 1988.

10. National Center for Health Statistics. CDC growth charts: United States. [cited 2010 nov 10]. Available from: http://www.cdc.gov/ nchs/about/major/nhanes/growthcharts/datafiles.htm.

11. Frisancho AR. Anthropometric standards for the assessment of growth and nutritional status. $1^{\text {st }}$ ed. Michigan: University of Michigan Press; 1993.

12. Tanner JM, Goldstein H, Whitehouse RH. Standards for children's height at ages 2-9 years allowing for heights of parents. Arch Dis Child. 1970;45(244):755-62.

13. Pankau R, Partsch CJ, Neblung A, Gosch A, Wessel A, Schaub J. Natural history of body mass index in Williams-Beuren syndrome. Am J Med Genet. 1994;52(1):51-4. 
14. Partsch CJ, Dreyer G, Gosch A, Winter M, Schneppenhein R, Wessel A, et al. Longitudinal evaluation of growth, puberty, and bone maturation in children with Williams syndrome. J Pediatr. 1999;134(1):82-9.

15. Morris CA, Demsey SA, Leonard CO, Dilts C, Blackburn BL. Natural history of Williams syndrome: physical characteristics. J Pediatr. 1988;113(2):318-26.

16. Pagon RA, Bennett FC, LaVeck B, Stewart KB, Johnson J. Williams syndrome: features in late childhood and adolescence. Pediatrics. 1987;80(1):85-91.
17. Lacroix A, Pezet M, Capel A, Bonnet D, Hennequin M, Jacob P, et al. Les syndrome de Williams-Beuren: une appproche pluridisciplinaire. Archives de Pédiatrie. 2009;16:273-282.

18. Morris C, Mervis C Willians syndrome and related disorders. Annu Rev Genomics Genet. 2000. 1:461-84.

19. Giannotti A, Tiberio M, Castro M, Virgilii F, Colistro F, Ferretti F et al. Coeliac disease in Williams syndrome. J Med Genet. 2001; 38:767-768 